future be surpassing highbrow and surpassing happy!"

The following sign poem was then delivered by Mr. Tafler, with musical accompaniment by the lecturer :

"Were I in future blind, yet would I always have A rainbow in my life, since you love me.

My red would be your lips, yellow your golden hair-

Your fragrance violet, and green scented leaves.
My blue would be your eyes, your arms would light my heart.

Your absence be my gloom, your soul $\rightarrow$ my sun!"

(At the conclusion of the discourse, a short extract was exhibited of a film under preparation by the Smithsonian Institution, Washington, on the Red Indian sign language. The extract showed the late General Scott performing the signs for the names of a number of Red Indian tribes.)

\title{
Obituary
}

\section{Mr. T. H. Pope}

$\mathrm{T}$ HOMAS HENRY POPE, who passed away on January 12, was born in London on February I, 1875. He received his early scientific education at the Finsbury Technical College and in 1893 entered the Central Technical College, South Kensington, as a student of chemistry under Prof. F. E. Armstrong. After gaining the diploma of associate of the City and Guilds Institute in 1896, he became research assistant, first to Prof. W. C. Unwin and afterwards to Mr. (now Sir) Robert Mond until 1898, when he joined Julian L. Baker, then chief chemist to the Beetroot Sugar Association. In 1900 he became himself chief chemist to that Association, and shortly afterwards, in 1901, was appointed lecturer and demonstrator in the British School of Malting and Brewing under the late Prof. Adrian Brown. Pope stayed at the Birmingham School of Brewing until October 1917, when he joined Messrs. Calder's, Ltd., working at the distilleries at Bo'ness and Gartloch on problems arising in alcohol and yeast manufacture. This firm became an associated company of the Distillers Company, Ltd., in 1922, when T. H. Pope was transferred, first to the Vauxhall Distillery, Liverpool, and later, 1925, to Bankhall Distillery, in the same city. In 1927 he went as one of the senior chemists to the Research Department of the Distillers Company, then newly established at Great Burgh, Epsom, where he remained until the time of his death.

T. H. Pope was essentially a student, and devoted most of his spare time to the study of languages and to scientific literary work. He was an abstractor to the Journals of the Chemical Society and of the Society of Chemical Industry for more than thirtyfive years, and also did valuable work for the Society of Public Analysts, first as an abstractor, later, in 1933, as assistant editor of the Analyst. Up to the time of his death, he had for a number of years contributed abstracts of Italian scientific papers to Nature. He had a wide knowledge of foreign languages, including Spanish, Italian and Russian, and his translations of standard works such as Euler's "Chemie der Enzyme", Molinari's "Trattato di
Chimica Generale ed Applicata all'Industria" and Villavecchia's "Trattato di Chimica Analitica Appli. cata", are well known.

Pope will be greatly mourned by all who knew him. He had an essentially critical mind, combined with a courtly dignity and quiet humour, which made him a most agreeable colleague. His wide reading and appreciation of detail were of very great service in the study of large-scale operations, with which he was occupied in his later years.

\section{J. VARgas EYre.}

\section{Mr. F. A. Bellamy}

Frank Arthur Bellamy, who died suddenly on February 15 at the age of seventy-four years, started his astronomical career in 1881 as an assistant at the Radeliffe Observatory at Oxford, where his two elder brothers had been before him. Eleven years later he was selected by Prof. Pritchard to be his assistant at the University Observatory at Oxford. When H. H. Turner succeeded to the Savilian chair two years later, the share of the Astrographic Catalogue which Pritchard had accepted was in its inception; a suitable telescope had been presented to the Observatory by Warren de la Rue; and to Bellamy fell a large share of the taking of the plates, the measurement of some 400,000 star images, the reduction of the measures, and the preparation of the results for publication. That a piece of work of this magnitude could be carried out in a reasonable time at an observatory with such a meagre staff was mainly due to the ingenious methods of measurement and reduction introduced by Turner, but its com. pletion within the short period of ten years owes much to the enthusiasm and assiduity which Bellamy devoted to it.

The passing through the press under Bellamy's supervision of the seven volumes of measures was not completed until 1911, but no sooner was this done than Prof. Turner offered a helping hand to the Vatican Observatory, which had undertaken a section of the Catalogue and was finding it more than it could manage. The plates were taken in 
Rome and measured there by members of a sisterhood, and the reductions were carried out by Bellamy, now assisted by his niece. In recognition of this work Prof. Turner and his two assistants each received a medal from the Pope. Just before his death, Turner undertook a part of the Potsdam zone relinquished by that Observatory after the War. Bellamy was not so young as he had been, but he managed nearly to finish this piece of work before he died. He was a good example of the accurate and painstaking assistant to which British astronomy has owed so much in the past. He received the degree of M.A. honoris causa from the University of Oxford.

\section{Mr. George A. Macmillan}

We regret to record the death of $\mathbf{M r}$. George A. Macmillan, which took place at Botton Hall, Danby, on March 3 at the age of eighty years. George Augustus Macmillan was born at Cambridge on August 1, 1855, and was educated at Eton. On leaving school in $\mathbf{1 8 7 3}$ he joined the publishing house founded by his father and uncle, becoming a partner in 1879 and later a director, when the business was converted into a company.

Outside the claims of his business career, George Macmillan was deeply interested in farming and music; but the chief devotion of his life was to the literature, history and archæology of Greece and Rome. Not only was he a close personal friend of the most eminent classical scholars of his day, such as J. P. Mahaffy, Sir Richard Jebb, Sir Arthur Evans and Sir James Frazer, but also he freely gave the full force of his business ability and organising powers to the promotion of the studies in which lay their common interests. British scholarship, more especially the study of the archæology of classic lands, is deeply indebted to him for his ceaseless efforts on behalf of the Society for the Promotion of Hellenic Studies, which celebrated its fiftieth anniversary in 1929. Not only was he one of the most active of its original promoters, but he also served as its honorary secretary for forty years, retiring in 1919 to become its treasurer until 1934. He also served as president.

The foundation of the British School of Archæology at Athens was largely due to Mr. Macmillan's activities, and he also took a part in the founding of the Society for the Promotion of Roman Studies. $\mathrm{He}$ was a member of the Managing Committee of the British School and afterwards chairman; and it was largely due to his energy and ability in the conduct of its affairs that the great achievement of the School was made possible. His intimate knowledge of the Hellenic Society and the School gives the history of each which he wrote an unquestionable authority. His services are commemorated in the Macmillan Hostel at Athens and the Macmillan Studentship, which he himself founded. His numerous benefactions and services to scholarship were recognised by the honorary degree of D.Litt. conferred on him by the university of Oxford, and an honorary fellowship of Lincoln College, Oxford.

WE regret to announce the following deaths:

Dr. F. B. Allan, professor of organic chemistry in the University of Toronto, on January 9, aged sixtyeight years.

Dr. R. G. Harris, director of the Biological Laboratory, Cold Spring Harbor, an authority on the physiology of reproduction, on January 7, aged thirty-seven years.

Dr. Heinrich Lumpe, known for his work on the protection of birds, and the establishment of bird sanctuaries, especially in Bohemia, aged seventy-six years.

Prof. I. P. Pavlov, For.Mem.R.S., Copley medallist of the Royal Society in 1915, on February 27, aged eighty-six years.

\section{News and Views}

\section{The King's Message}

"IT has been an ancient tradition of the British monarchy that the new Sovereign should send a message to his peoples. Science has made it possible for me to make that written message more personal, and to speak to you all over the radio." Thus H.M. King Edward VIII on March 1, in words eloquent in their simplicity, marked an occasion which he himself, no less than the countless millions of his subjects and peoples of other nations who 'listened in', cannot but have felt will live as ever memorable in history. Never has ancient ceremonial been wedded more impressively to the progress of science. It is surely a good omen for the advancement of science that the potentialities of its application to ends which may seem remote from the laboratory of the research worker, should be emphasised on such an occasion by one who not only has availed himself freely of its aid in many ways in the performance of his official functions in the past, but also will be able in the future to do much to guide and influence public opinion towards a scientific approach to the problems of the State and the needs of daily life. It is perhaps permissible to feel in the King's affectionate and reverent reference to the acts and qualities by which his father won the deep-rooted loyalty of his people, as well as in the message of thanks for the people's sympathy from himself, his mother and the members of his family, an undercurrent of dedication of himself to a like personal service and sympathetic under- 